\title{
HasanuddinLawReview
}

\section{The Anomaly of the Village Government in Establishing Village Owned Enterprise}

\author{
Busyra Azheri', Upita Anggunsuri ${ }^{2}$ \\ ${ }^{1}$ Faculty Law, Andalas University, Indonesia. E-mail: ba1969bd@gmail.com \\ 2 Faculty Law, Andalas University, Indonesia. E-mail: upitaanggun@gmail.com
}

\author{
ARTICLE INFO \\ Keywords: \\ Authority; Autonomy; Local \\ Government; Village \\ Government; Village Owned \\ Enterprise \\ How to cite: \\ Azheri, B., and Anggunsuri, \\ U. (2018). "The Anomaly of \\ the Village Government in \\ Establishing Village Owned \\ Enterprise," Hasanuddin \\ Law Review, 4(2): 256-264 \\ DOI: \\ 10.20956/halrev.v4i2.1299
}

\begin{abstract}
Village Owned Enterprise is an important part of the form of empowerment economic community at the village. Given, the urgency of the existence of Village Owned Enterprise, the government through the Regulation of Ministry of Villages, Disadvantaged Regions and Transmigration No. 5 of 2015 stated that one of the priorities of the use of village funds is for the establishment and development of Village Owned Enterprise. While the mechanism of establishment of Village Owned Enterprise is based on the result of village consultative meeting involving element of village government, element of village consultative body, and elements of community figures. The result of the village consultative meeting is implemented in form Village Regulation. However, it causes anomaly related to the status of Village Owned Enterprise, because it does not have to be legal entity in Regulation of Ministry of Villages meanwhile it has to be legal entity in Regulation of Minister of Home Affairs No. 39 of 2010 on Village Owned Enterprise.
\end{abstract}

Copyright (C) 2018 HALREV. All rights reserved.

\section{Introduction}

Since the enactment of the Law No. 22 of 1999 on Local Government, local autonomy has become the focus of Central and Local Government. However, the acceleration of regional autonomy policy is supported by the enactment of a set of regulations on local government, the management of regional financial, and the balance of central and regional finance. The authority of the village includes the authority of Village Administration, the implementation of village development, the development of village community, and the empowerment of village community based on community initiatives, the right of the origin and village' custom. ${ }^{1}$ Hence, it is expected that the region can set up and manage their own affairs.

\footnotetext{
1 Article 18 of the Law No. 6 of 2014 on the Village Government.
} 
In addition to having the right to fully regulate their own household affairs, the village also has an obligation to realize the objectives of village management, such as: to improve public services for the citizens of the village community in order to accelerate the realization general welfare and overcome the disparity of national development and strengthen the village community as a subject of development. ${ }^{2}$ To achieve those objectives, the village needs to implement various strategies so the allocation, potency and resource in the village can be streamlined to support the realization of village development to increase the quality of life and life to the welfare of the villagers by establishing a Village Owned Enterprise. ${ }^{3}$ Because of that village competes to establish Village Owned Enterprise even though the legal standing has not been prepared.

In line with the concept of autonomy, there are two ways to obtain governmental authority: attribution and delegation; sometimes, mandate, is placed as a separate way to gain authority. ${ }^{4} \mathrm{~A}$ mandate is defined as an assignment of authority to a subordinate. As for the mandate there is no delegation of any kind in the sense of giving authority, the mandated official acting for and on behalf of the mandator. In the mandate, the mandate officer appoints another official (mandate) to act on the behalf of Mandan's (mandator). ${ }^{5}$ Thus, as a concept of public law, authority consists of three components, namely: 6

a. The component of influence is that the use of authority is meant to control the behavior of legal subjects;

b. The basic components of the law that the authority must always be subject to its legal basis; and

c. The conformity component implies the existence of a standard of authority that is the general standard (all types of powers) and special standards (for certain types of authority).

The discussion more deeply about the authority of the village, it can be said that Village Owned Enterprise is an economic institution at the village level which is attempted as a means of improving people's welfare. Village Owned Enterprise is an important part of the form of empowerment economic community at the village. Since it is regulated in Law No 6 of 2014 on Village. In fact, the Regulation of the Minister of Home Affairs Number 39 of 2010 state that the existence of Village Owned Enterprise as a center for the development of community economic programs by promoting the principle of transparency and accountability to society. The establishment of Village Owned Enterprise is a new innovation that proper to be appreciated. At least Village Owned Enterprise become a new form of community business ownership that can push the process of economic equity to the villages that have been ignored. 7

Based on the description above, there are two current issues related to the authority of the Village Government to establish Village Owned Enterprise: Firstly, what is the provision as basic of the authority of the Village Government to establish Village Owned

\footnotetext{
Articlel 4 Law No 6/2014 On Village

Article 1 (8) Law No 6/2014 On Village

Ridwan, H.R. (2008). Hukum Administrasi Negara. Jakarta: PT RajaGrafindo Persada. p. 104.

Hadjon, P. M. (1998). “Tentang Wewenang Pemerintahan (Bestuurbevoegdheid)". Pro Justitia, Ikatan Alumni Fakultas Hukum Universitas Parahyangan Bandun Tahun XVI Nomor, 1.

Ibid.

Syahputra, E. (2017). Pengentasan Kemiskinan Melalui Hukum Sebagai Sarana Pemberdayaan CSR (Corporate Social Responsibility) Dalam Kegiatan Pertambangan Emas Di Tapanuli Selatan (Dissertation), Semarang: Universitas Diponegoro.
} 
Enterprise; Secondly, what is the mechanism of the establishment Village Owned Enterprise based on legislation.

\section{The Basic Authority of Village Government to establish Village Owned Enterprise}

The village government has the autonomy to regulate and implement the government based on authority attributively. In other words, the term of autonomy has a transfer of authority from the level of government. Given the autonomy that has been granted to the village, the granting of authority is a right owned by a village to be able to manage the household. Village Government is the Village Head or as referred to by any other name assisted with Village apparatus as the administrative element of the village governance. ${ }^{8}$ Although Law on Village has granted authority to the village Government, it cannot be done indefinitely. Therefore, the implementation of authority based on attribution must be in line with the principle of village regulation as defined in Article 3 of the Village Law relating to the principle of village governance, such as mutual cooperation, deliberation, democracy, independence, participation, empowerment and sustainability.

As an autonomous region, villages deserve a source of income. ${ }^{9}$ The source of village income is the wealth of villages managed based on the principles of the principle of common interests, functional, legal certainty, transparency, efficiency, effectiveness, accountability, and the certainty of economic value. ${ }^{10}$ The wealth of the village is a village asset that should be utilized by the present and future villagers. Village Asset shall be the property of the Village from the original wealth of the Village, purchased or obtained at the expense of the Village Budget or other legal rights. ${ }^{11}$ Therefore, the Village asset management shall be done to improve the welfare and living standards of the Village community as well as increase Village revenue. ${ }^{12}$

Management of village assets is a series of activities that includes planning, procurement, utilization, securing, maintenance, elimination, handover, administration, reporting, assessment, guidance, supervision, and control of Village assets. ${ }^{13}$ In managing of village property the Village Head along with the Village Consultative Body based on the Village asset management procedures set out in the government regulation. ${ }^{14}$ Village Government shall be the Village Head or as referred to by any other names assisted the by the Village apparatus as parts of administrators of the Village. The Village head shall be the bearer of authority of Village asset management. ${ }^{15}$

Above all, Village Owned Enterprise is a business entity of all or most of the capital owned by the Village through direct participation from the separated assets of the Village in order to manage assets, services, and other business for the greatest welfare of the Village community. Thus, Village original revenue is one of the income original

8 Article 1 (3) Government Regulation No 43/2014 on Implementing Regulation of Law No 6/2014 on Village

9 Article 67 (1) Law No. 6 of 2014 on Village.

10 Article 77 (1) Law No. 6 of 2014 on Village.

11 Article 1 (11) Law No. 6 of 2014 on Village.

12 Article 77 (2) Law No. 6 of 2014 on Village juncto Article 110 (1) Government Regulation No 43/2014 On Implementing Regulation of Law No 43/2014 On Village

13 Article 108 Government Regulation No 43/ 2014 On Implementing Regulation of Law No 6/2014 On Village

14 Article 77 (3) Law No 6/2014 On Village.

15 Article 109 (1) Government Regulation N o 43/ 2014 On Implementing Regulation of Law No 6/2014 on Village 
revenue of the village. Village original revenue shall be revenue derived from the authority of the Village of based on rights of origin and Village scale local authority. Thus, the income of Village Owned Enterprise is one of village original revenue.

On the other side, it should be understood that the establishment of Village Owned Enterprise is a promise of national development as an effort to help accelerate development to the village. This provision is explicitly affirmed by Article 87 Paragraph (1) of the Law No. 6 of 2014 states that the Village may establish a Village Owned Enterprise juncto Article 132 paragraph (1) of Government Regulation No. 43 of 2014 on the Implementing Regulation No. 6 of 2014 on the Village. Government. Nevertheless, the word "can" in all these rules does not necessarily exist, but if the existence of Village Owned Enterprise can support of the society economy in the village then the Village Government needs to consider it.

In the explanation of Article 87 paragraph (1) of the Law No. 6 of 2014, states that Village Owned Enterprise shall be formed by the Village government to utilize all the economic potency, economic institution, natural resources and human resources in order to improve the welfare of the Village community. Therefore, the establishment of Village Owned Enterprise should be based on the needs and potency of the village, as an effort to improve the welfare of the citizen. Therefore, the establishment of Village Owned Enterprise should be characterized by the existing localities and economic capacity of the village.

In addition, the effort to realize the establishment of Village Owned Enterprise can also be pioneered by optimizing the capacity and economic activities that have managed by the village. Therefore, planning and establishment village, should be built on initiative of society. Participating the society in establishing of Village Owned Enterprise, so it will cause a sense of belonging of society, so the community will participate to development and management.

Consequently, it should be understood also that Village Owned Enterprise specifically cannot be equated with business entities in general, such as Limited Liability Company (PT), CV, or Koperasi. This needs to be emphasized, that Village Owned Enterprise is a business entity that has characteristic of village in implementing it. Besides, to assist the implementation of Village Government, as well as to fulfill the needs of the village community. ${ }^{16}$ Hence, Village Owned Enterprise can also run the functions of services, trade and other economic development. Therefore, Village Owned Enterprise not only oriented to profit, but also the improvement of welfare of village communities. However, based on the purpose, objectives and the capital, Village Owned Enterprise more emphasis to profit oriented.17

Village Owned Enterprise is also expected to stimulate and drive of the economy in village. The economic assets of village should be managed by the village community. The substance and philosophy of Village Owned Enterprise should be embedded as an effort to strengthen the institutional economic aspect. ${ }^{18}$ In this condition, Village Owned Enterprise will effort to increase income village and to empower the economic activities of the village community as well as the function of Village Owned Enterprise. This effort

16 Dewi, A.S.K. (2010). “Alternatif Bentuk Badan Hukum yang Tepat dalam Pendirian Badan Usaha Milik Desa (BUMDes) sebagai Upaya Meningkatkan Pendapatan Asli Desa (PADes)”, Jurnal Pamator, 3 (2): 116. 17 Ibid

18 Coristya, B.R., and Suwondo, H.R. (2013). “Artikel Keberadaan Badan Usaha Milik Desa (Bumdes) Sebagai Penguatan Ekonomi Desa (Studi Di Desa Landungsari, Kecamatan Dau, Kabupaten Malang)", Jurnal Administrasi Publik, 1(6): 1068-1076. 
is also important to reduce the role of free riders, which often increase transaction cost in economic activities.

However, based on reality the Village Owned Enterprise has 2 (two) functions, they are public service and/or in economic field. Village Owned Enterprise as a public service institution has social function that oriented to public interest through its contribution in services. While as a commercial institution aims to seek profits through the supply of local resources (goods and services) to the market. On the principle, Village Owned Enterprise must be in form of legal entity in line with applicable legislation, and in accordance with the agreement with the village community. ${ }^{19}$

\section{Establishment and Management of Village Owned Enterprise}

\subsection{The Establishment of Village Owned Enterprise}

The village government in establishing Village Owned Enterprise shall be based on Village Regulations guided by Local Regulation. The establishment of Village Owned Enterprise is done through village consultative meeting based on village regulation. ${ }^{20}$ Village Consultative Meeting or as referred to by any other name shall be a consultation between the Village Consultative Body, Village government, and community elements organized by the Village Consultative Body to agree on matters of a strategic nature. ${ }^{21}$ The strategic nature as referred to in paragraph Village structuring, Village planning, Village cooperation, plan of investment into the Village, Village Asset additions and disposals, extraordinary events. ${ }^{22}$ The establishment of Village Owned Enterprises is strategic, so before The establishment of Village Owned Enterprise shall be agreed by a Village Consultative Meeting. ${ }^{23}$

The provision of Article 80 paragraphs (1), (2) and (3) Regulation of Minister of Home Affairs Number 39 of 2010 on Village Owned Enterprises, Village Consultative meeting is held by Village Consultative Body facilitated by the Village Government. The Village Consultative meeting was attended by Village Government, Village Consultative Body, and citizen. Citizen element consists of traditional leaders, religious leaders, community leaders, education figures and other group representatives. The establishment of Village Owned Enterprise should also be discussed with the Village Consultative Body because one of functions of the Village Consultative Body is to discuss and agree on Draft Village Regulation along with the Village Head.24

In line with the provision of Article 88 paragraph (2) of the Law No 6/2014 on Village, after getting approval of village consultative meeting, the next step is to stipulate the village regulation related to the establishment of Village Owned Enterprise. This is important because village regulations are legislation established by the Village Head after being discussed and agreed with the Village Consultative Body.

19 Sihabudin., Dewi, A.S.K., and Prasetyo, N.D. (2009). “Konstruksi Bentuk Badan Hukum Badan Usaha Milik Desa (Bumdes) Berbasis Potensi Ekonomi Desa Sebagai Upaya Pemberdayaan Masyarakat Sekitar Hutan Di Desa Sumber Bendo Kecamatan Saradan Kabupaten Madiun," Jurnal Ilmu Sosial (Social Sciences), 21 (1).

20 Article 132 (2) Government Regulation No 43/ 2014 On Implementing Regulation of Law No 6 /2014 on Village.

21 Article 1 (5) of the Law No. 6 of 2014 on Village.

22 Article 54 (2) of the Law No. 6 of 2014 on Village.

23 Article 88 (1) of the Law No. 6 of 2014 on Village.

24 Article 55 of the Law No. 6 of 2014 on Village. 
According to Article 5 paragraph (1) Regulation of Minister of Home Affairs Number 39 of 2010 on Village Owned Enterprises, the requirements for establishment of Village Owned Enterprise are as follows:

a. Initiative of village community and/or village government based on village consultative meeting.

b. The potency economic of village community.

c. In accordance with the needs of the village community, especially in fulfillment of basic needs

d. the availability of village resources that have not been utilized optimally, especially the village's wealth.

e. The availability of human resources that manage business entity as an asset of rural communities

f. The business entity of citizen is managed partially and less accommodated

g. To increase the income of the community and the village original revenue

\subsection{The Management of Village Owned Enterprise}

Referring to Article 5 of Regulation of Minister of Home Affairs Number 39 of 2010 on Village Owned Enterprises, in the step of establishment of Village Owned Enterprise must be prepared who will run the Village Owned Enterprise. The organization of Village Owned Enterprise is separate from the village government organization. ${ }^{25}$ So the manager of Village Owned Enterprise is also separate from the manager of the village government organization. This is important because manager is the main resource that can run the organization.

Based on the provisions of Article 132 paragraph (4) and (5) of the Minister of Home Affairs Regulation No. 39/2010, Village Owned Enterprise consisted of operational advisors and operators. The advisor as ex-officio held by the Village Head. The advisor has the duty to supervise and give advice to the operational employee in running the village business. In addition, the advisors in carrying out their duties have authority to ask for an explanation of the operational employee related to the management of the village businesses.

In addition, according to Article 132 paragraph (6) and (7) the Minister of Home Affairs Regulation Number 39 of 2010 on Village Owned Enterprise, the Head of Village as an advisor can point and dismiss the operational employee as an individual. Therefore, the operational employee shall be prohibited from holding multiple positions that perform the implementing functions of the Village Government institutions and Village community institutions. The operational employee consists of director or manager and head of business units. The operational implementer has the duty to manage in accordance with the articles of association and the household budget.

\subsection{The Capital of Village Owned Enterprise}

As explained earlier, the source of capital Village Owned Enterprise comes from the placement and separation of the village's own funds through the Village Regulation. However, to expand its business activity, Village Owned Enterprise may receive loan and/or assistance from other parties. ${ }^{26}$ As an effort to increase the source of village

25 See, Article 6 of the Regulation of Minister of Home Affairs No. 39 of 2010 on Village Owned Enterprise

26 Article 137 (1) Government Regulation No. 43 of 2014 on Implementing Regulation of Law No 6 2014 on Village. 
income, Village Owned Enterprise can collect savings from local level of village communities, among others through the management of revolving funds and savings and loans. Village Owned Enterprise in its activities not only oriented to the financial benefits, but also oriented to support improving the welfare of villagers. Village Owned Enterprise is expected to develop business units in utilizing potency economy

In addition to capital sources, it should be emphasized that Village Owned Enterprise acts as a stimulator of the economy in the countryside. The substance and philosophy of Village Owned Enterprise must be imbued with the spirit of togetherness and self-help as an effort to improve the economic and institutional aspects. Therefore, the government and village communities have a strategic role in the development of Village Owned Enterprise to empower the economy of village community. As a populist economic enterprise, Village Owned Enterprise does not transform into a profitable economic enterprise, if it is not managed properly, it will harm or come new problem for the village community.

Here is an important point that need to be done development and supervision of the management of Village Owned Enterprise, because not all elements of government and village community know and have a good entrepreneurship spirit. Therefore, it needs to arrange and formulate an effective Village Owned Enterprise guidance and supervisory pattern. On the other hand, Village Owned Enterprise is also impossible to develop without the support of all parties including all stakeholders.

As a result, the initial capital of Village Owned Enterprise shall originate from the Village Budget so the asset owned by Village Owned Enterprise are the wealth of the Village which is separated and not divided into shares. Wealth of Village Owned Enterprise is not divided into shares because the ownership is fully owned by the village. However, after Village Owned Enterprise stand, its capital consists of two sources, they are: Village capital investment and Village community capital investment. Hence, Village capital investment can come from the Village Budget and other sources. Village community capital investment can from fresh capital, Government assistance, regional government assistance and Village assets submitted to the Village Budget. For the Government assistance and Local Government, the mechanism will be distributed by village budget.

\subsection{The Capital of Village Owned Enterprise}

When the establishment of Village Owned Enterprise, it should be prepared concerning the draft of Statute of establishment. It needs to be done, so there is agreement to establish the Village Owned Enterprise, structure of organization including organization's guidance and can be used as operational guidance of Village Owned Enterprise. Therefore, the operational implementer/employee of Village Owned Enterprise is obliged to arrange and stipulate statute after getting consideration of the head of Village. ${ }^{27}$

In accordance with the provision of Article 136 paragraph (2) of the Government Regulation No. 43 of 2014 state that statute contains at least the name, domicile, purpose and objectives, capital, enterprise activity, time period for the establishment of the Village owned Enterprise, managing organization, as well as procedures for usage and sharing of profits. The name of Village Owned Enterprise needs to be prepared at the planning of establishment, because it will be branding. The domicile of Village Owned

27 Article 153 (1) Government Regulation No. 43 of 2014 on Implementing Regulation of Law No 6 2014 on Village. 
Enterprise also needs to be agreed, it will be the center of Village Owned Enterprise activities. In addition, the purpose and objective of the establishment of Village Owned Enterprise in line with the development of the village. While, the amount of initial capital for the establishment of Village Owned Enterprise is a very urgent thing, because one of the sources of capital comes from the separated village assets. Therefore, related to the capital of Village Owned Enterprise needs the legal standing.

While the statute of Village Owned Enterprise contains at least state the rights and obligations, service period, procedures for appointment and dismissal of the managing organization personnel, establishment of type of activities, and source of capital. These rights and obligations should be included in statute, so managers and stakeholders can know the rights and obligations of each other. In addition, it is also important to include working period of Village Owned Enterprise in order to know the period of stewardship. Besides, the procedure for appointment and dismissal of the managing organization personnel of Village Owned Enterprise should be included in the statute so the procedure for appointment and dismissal of managers is clear.

\section{Conclusion}

The existence of Village Owned Enterprise is a stimulus to accelerate the economic growth of village communities and to improve their welfare. Normatively, the provision that can be basic of the authority of Village Government is Article 87 of the Law No. 6 of 2014 on the village government and Article 371 of the Law No. 23 of 2014 on the Local Government, which has delegated some authorities from the provincial and district/city government to the village as the effort to improve the welfare of the village community. The procedure of establishment of Village Owned Enterprise should be based on Village Regulation that are guided by the Local Regulation. Establishment of Village Owned Enterprise is done through village meetings established by village regulation. In accordance with the provisions of Article 80 paragraphs (1), (2), and (3) Minister of Home Affairs Regulation No. 39 of 2010 on the Village Owned Enterprises, Village Consultative meeting is followed by Village Government, Village Consultative Body, and community elements. Community elements may consist of traditional leaders, religious leaders, community leaders, education figures and other group representatives. Then, the Manager of Village Owned Enterprise at least consists of advisors and operational employee. The Advisor is served as ex-officio by the Head of Village. Then, the capital comes from the placement and separation of village funds through the Village Regulation.

\section{References}

Coristya, B.R., and Suwondo, H.R. (2013). “Artikel Keberadaan Badan Usaha Milik Desa (Bumdes) Sebagai Penguatan Ekonomi Desa (Studi Di Desa Landungsari, Kecamatan Dau, Kabupaten Malang)", Jurnal Administrasi Publik, 1(6): 1068-1076.

Dewi, A.S.K. (2010). “Alternatif Bentuk Badan Hukum yang Tepat dalam Pendirian Badan Usaha Milik Desa (BUMDes) sebagai Upaya Meningkatkan Pendapatan Asli Desa (PADes)", Jurnal Pamator, 3 (2): 116.

Hadjon, P. M. (1998). “Tentang Wewenang Pemerintahan (Bestuurbevoegdheid)". Pro Justitia, Ikatan Alumni Fakultas Hukum Universitas Parahyangan Bandun Tahun XVI No., 1. 
Ridwan, HR. (2008). Hukum Administrasi Negara. Jakarta: PT RajaGrafindo Persada. p. 104.

Sihabudin., Dewi, A.S.K., and Prasetyo, N.D. (2009). “Konstruksi Bentuk Badan Hukum Badan Usaha Milik Desa (Bumdes) Berbasis Potensi Ekonomi Desa Sebagai Upaya Pemberdayaan Masyarakat Sekitar Hutan Di Desa Sumber Bendo Kecamatan Saradan Kabupaten Madiun," Jurnal Ilmu Sosial (Social Sciences), 21 (1).

Syahputra, E. (2017). Pengentasan Kemiskinan Melalui Hukum Sebagai Sarana Pemberdayaan CSR (Corporate Social Responsibility) Dalam Kegiatan Pertambangan Emas Di Tapanuli Selatan (Dissertation), Semarang: Universitas Diponegoro.

Regulations

Law No. 23 of 2014 on the Local Government

Law No. 6 of 2014 on the Village Government

Government Regulation No. 72 of 2005 on the Village Government

Government Regulation No. 43 of 2014 on Implementing Regulation for Law No. 6 of 2014 on the Village Government

Regulation of the Minister of Home Affairs Number 39 of 2010 on the Village Owned Enterprise 